\title{
PENGEMBANGAN KARAKTER SOPAN SANTUN MELALUI KEGIATAN BERMAIN PERAN PADA ANAK USIA DINI DI TK ADIRASA JUMIANG
}

\author{
Qurratul Aini \\ IAIN Madura \\ Email: qurratulaini539@gmail.com
}

\begin{abstract}
This study aims to find out how the application of the role playing method in developing the character of courtesy in children. The subject of this study was the children of group B RA Adirasa Jumiang Muballighin II. The data collected is in the form of character of children's courtesy and the process of applying the role playing method in learning. This research is a qualitative research with a case study approach. The results showed that there was an increase in the character of child courtesy from Cycle I to Cycle III. The average percentage of the achievement of the ability of the character of good manners increased consecutively from pre-cycle, cycle I and cycle III. $45 \%$ respectively in the pre-cycle conditions increased to $70 \%$ in the first cycle, $22.62 \%$ in the second cycle. While the number of children who have completed learning or achieved a percentage of success of $75 \%$ also continues to have children whose percentage of achievement is categorized as developing. And in cycle III, many children have experienced an increase, one of which can be coloring according to their own creation and can not exceed the line when coloring.
\end{abstract}

Keywords: role playing methods, character manners

\begin{abstract}
Abstrak
Penelitian ini bertujuan untuk mengetahui bagaimana penerapan metode bermain peran dalam mengembangkan karakter sopan santun pada anak. Subjek penelitian ini adalah anak kelompok B RA Adirasa Jumiang Muballighin II. Data yang dikumpukan berupa karakter sopan santun anak dan proses penerapan metode bermain peran dalam pembelajaran. Penelitian ini merupakan penelitian kualitatif dengan pendekatan studi kasus. Hasil penelitian menunjukkan bahwa terjadi peningkatan karakter sopan santun anak dari Siklus I sampai dengan Siklus III. Rata-rata persentase pencapaian kemampuan karakter sopan santun anak meningkat berturut-turut dari prasiklus, sikus I dan siklus III. Berturut-turut $45 \%$ pada kondisi prasiklus meningkat menjadi $70 \%$ pada siklus I, 22,62\% di siklus II. Sedangkan jumlah anak yang tuntas belajar atau mencapai prosentase keberhasilan sebesar $75 \%$ juga terus anak yang prasentase pencapaiannya yang berkatagori mulai berkembang. Dan pada siklus III, anak sudah banyak mengalami peningkatan salah satunya bisa mwewarnai sesuai dengan kreasinya sendirai dan sudah bisa tidak melebihi garis ketika mewarnai.
\end{abstract}

Kata Kunci: metode bermain peran, karakter sopan santun 


\section{PENDAHULUAN}

Usia dini merupakan masa kritis bagi pembentukan karakter seseorang. Banyak pakar pendidikan mengatakan bahwa kegagalan penanaman karakter sejak dini akan membentuk pribadi yang bermasalah di masa dewasanya kelak. Anak-anak akan tumbuh menjadi pribadi yang berkarakter jika dapat tumbuh pada lingkungan yang berkarakter, sehingga fitrah setiap anak yang dilahirkan suci dapat berkembang secara optimal.

Salah satu pilar karakter menurut megawangi (2007:25) adalah hormat dan santun. Anak dibiasakan bersikap sopan santun dalam kehidupan sehari-hari baik dalam bergaul dalam satu keluarga maupun dengan lingkungan. Seperti yang diungkapkan oleh kusma (2009) dalam yaitu: “ kelak, anak yang dibiasakan dari kecil untuk bersikap sopan santun akan lebih mudah bersosialisasi pada teman sebayanya dan gurunya. Dia akan mudah memahami aturan-aturan yang ada dimasyarakat dan mau mematuhi aturan umum tersebut. Anak pun relatif mudah menyesuaikan diri dengan lingkungan baru, supel, selalu menghargai orang lain, penuh percaya diri, dan memiliki kehidupan sosial yang baik. Pendek kata, dia tumbuh menjadi sosok yang beradab.

Fakta yang muncul di kelompok B Taman kanak-kanak (TK) Adirasa jumiang adalah, masih ada beberapa anak didik yang tidak mendengarkan guru berbicara, suka main sendiri disaat pelajaran dimulai, tidak mengucapkan salam ketika berjumpa dengan guru atau teman, dan ada juga sebagian anak yang mengikuti apa yang guru katakan. Karena setiap karakter anak itu berbeda-beda. Pada fakta tersebut tentu saja menyebabkan berbagai macam permasalahan dalam pembelajaran. Hal yang paling sering terjadi adalah kelas menjadi tidak bisa diatur. Hasil penelitian dan percobaan yang telah dilakukan oleh para ahli menunjukkan bahwa bermain peran merupakan salah satu model yang dapat digunakan secara efektif dalam pembelajaran (Hurlock, 2006:76). Dalam hal ini, bermain peran diarahkan pada pemecahan masalah yang menyangkut hubungan antara manusia, terutama yang menyangkut kehidupan anak didik.

Pengenalan karakter untuk anak usia dini melalui bermain peran tidak hanya dirangsang dengan media bergambar dalam bentuk buku cerita, namun dapat pula dengan boneka-boneka, wayang, dan berbagai media agar anak belajar memahami jalan cerita yang konkrit. Pengembangan karakter memerlukan keteladanan dan sentuhan mulai sejak dini sampai dewasa. Sebab, pada dasarnya, anak yang berkarakter rendah adalah anak yang tingkat perkembangan emosi sosialnya rendah sehingga anak beresiko megalami kesulitan belajar., berinteraksi sosial, dan tidak mampu mengontrol diri. Usia dini merupakan masa persiapan untuk sekolah yang sesungguhnya, maka pengembangan karakter yang baik di usia dini merupakan hal yang sangat penting untuk dilakukan.

Pembentukan karakter pada anak usia dini dilakukan melalui pembiasaan bercerita. Adapun tujuannya adalah agar anak mempraktekan langsung nilai-nilai tersebut dan terbiasa untuk melakukan hal-hal yang baik dengan harapan nilai tersebut dapat terinternalisasi dalam kehidupan anak. Sesuai dengan tahap perkembangan moral anak. Penanaman nilai pendidikan pada anak usia dini sesuai pp.58 suplemen kurikulum mencakup empat aspek yaitu aspek spiritual, aspek personal, aspek sosial dan aspek lingkungan. Nilai-nilai yang dianggap baik dan penting untuk dikenalkan dan diinternalisasikan untuk anak usia dini sesuai suplemen pp.58 yaitu mencangkup; kecintaan terhadap Tuhan Yang Maha Esa, kejujuran, disiplin, toleransi dan cinta damai, percaya diri, hormat dan sopan santun, kerja sama dan gotong royong, dan lain-lain.

Secara etimologis sopan santun baerasal dari dua buah kata, yaitu kata sopan dan santun. Keduanya telah bergabung menjadi sebuah kata majemuk. Dalam kamus besar bahasa Indonesia menyatakan sopan santun sebagai berikut: sopan berarti hormat dengan tak lazim, tertib menurut adab yang baik, sedangkan santun berarti halus dan baik (budi 
bahasanya, tingkah lakunya); sopan, sabar; tenang. Atau bisadikatakan cerminan psikomotorik (penerapan pengetahuan span ke dalam suatu tindakan).

Sikap sopan santun sangat dipengaruhi oleh lingkungan. Orang tua, guru dan teman sebaya menjadi salah satu yang berperan penting dalam mempengaruhi sikap sopan santun anak. Orang tua, guru dan teman sebaya biasanya dijadikan sebagai role model bagi anak dalam bertindak, berperilaku serta bersikap karena pada fase-fase awal kehidupan, anak banyak sekali belajar melalui peniruan terhadap kebiasaan dan tingkah laku orang-orang disekitarnya (Syarbini. 2012, hlm. 65). Orang tua maupun guru harus selalu menunjukkan sikap sopan santun karena secara otomatis anak akan mengadopsi tata krama tersebut dalam berperilaku sehari-hari (Kusuma, dalam Ujiningsih. 2010, hlm 4). Selain itu, orang tua, guru harus memberikan pengaruh edukatif seluas-luasnya kepada anak, agar dapat membantu mengembangkan perilaku anak yang positif, karena perilaku ini dapat terbentuk melalui interaksi dan kebiasaan sehari-hari.

Sikap soapn santun dalam kurikulum 2013 PAUD termasuk pada kompotensi inti-2 (KI-2) untuk kompotensi inti sikap sosial dengan kompotensi dasar sikap sosial (KD-2) yaitu 2.14 memiliki perilaku yang mencerminkan sikap rendah hati dan santun kepada orang tua, pendidik dan teman. Sikap ini tercermin dari perilaku anak seperti tidak angkuh, ramah menyapa siapa pun, bermuka riang saat berbicara, tidak suka melebih-lebihkan diri sendiri, berbicara dengan santun dan suara lembut, sederhana, tenang, tidak pamer, memiliki sikap terbuka, tidak ingin menang sendiri, sopan dan hormat pada siapa pun, menghargai teman dan orang yang lebih tua usianya.

Sikap sopan santun sudah mulai diterapkan pada anak sejak anak memasuki sekolah. Khususnya di TK sikap sopan santun sudah mulai diterapkan dalam kegiatan pembelajaran, misalnya mengajarkan kepada anak untuk mengucapkan salam, membiasakan anak untuk mencium tangan guru, membiasakan anak berdo'a dengan tertib. Salah satu yang mempengaruhi perkembangan perilaku sopan santun anak adalah proses perlakuan atau bimbingan orang tua terhadap anak dalam mengenalkan berbagai aspek kehidupan sosial, atau norma-norma kehidupan bermasyarakat serta mendorong dan memberikan contoh kepada anaknya bagaimana menerapkan norma-norma tersebut dalam kehidupan seharihari.

Berdasarkan fakta tersebut, penulis segera mencari alternatif solusi untuk memecahhkan masalah tersebut. Alternatif solusi tersebut berupa penerapan kegiatan bermain peran dan dituangkan dalam sebuah penelitian yang berjudul "Pengembangan Karakter Sopan Santun melalui Kegiatan Bermain Peran pada Anak Taman Kanak-Kanak RA Adirasa Jumiang Muballighin II kecamatan ppademawu/kabupaten pamekasan Tahun pelajaran 2019-2020. Adapun penelitian ini bertujuan untuk mengembangkan karakter sopan santun melalui kegiatan bermain peran pada anak kelompok B RA Adirasa Jumiang Mubllighin II tahun pelajaran 2019-2020.

\section{METODE PENELITIAN}

Penelitian ini dilaksanakan di TK Adirasa jumiang selama setengah hari. Penelitiaan ini berbentuk penelitian tindakan kelas. Setiap langkah terdiri dari empat tahap yaitu perencanaan tindakan (planning), pelaksanaan tindakan (acting), pengamatan (observing), dan refleksi (reflecting). Sumber data penelitian adalah siswa yaitu karakter sopan santun anak. Sedangkan sumber data kedua adalah guru barupa kinerja guru selama penerapan pembelajaran. Sesuai dengan bentuknya, data kuantitatif dapat diolah atau dianalisis menggunakan teknik perhitungan matematika atau statiska. Data kuantitatif yang digunakan berupa data skor karakter sopam samtun siswa dan data proses penerapan pembelajaran. Sedangkan data kuantitatif berupa dokumentasi. 
Metode simulasi praktek yang diterapkan adalah observasi, catatan lapangan dan dokumentasi. Sedangkan instrumen penelitian yang digunakan dalam penelitian ini adalah : 1) lembar observasi yang terdiri dari atas lembar observasi kemampuan membaca awal anak dan lembar observasi penerapan pembelajaran melalui bermain kartu kata, huruf dan gamabar, 2) catatan lapangan, dan 3) dokumentasi.

Teknik analisis data yang diterapkan adalah analisis data kemampuan anak dilakukan dengan teknik analisis komparatif di mana data yang didapatkan pada setiap siklus kemudian dikomprasikan untuk melakukan refleksi, agar peneliti dapat menentukan tindakan yang akan diambil pada siklus berikutnya. Untuk menilai aspek kinerja guru dalam menerapkan metode bermain peran dilakukan dengan menggunakan Check list. Jawaban yang diberi skor 1, jawaban tidak diberi skor 0. Teknik pengecekan keabsahan data yang digunakan dalam penelitian ini yaitu merujuk Hopkins yaitu member check, triangulasi dan expert optinion.

Keberhasilan kegiatan penelitian ini akan tercermin dengan adanya peningkatan yang signitifkan terhadap karakter sopan santun anak didik sesuai dengan indikator dan bukti pengamatan yang telah ditetapkan. Adapun indikator keberhasilan penelitian tiap siklus ini adalah apabila sekurang-kurangnya $80 \%$ anak persentase pencapaian kemampuannya mampu mencapai persentase keberhasilan kemampuan minimum yang telah ditetapkan dalam penelitian ini yaitu $78 \%$.

\section{HASIL DAN PEMBAHASAN}

Untuk mengetahui awal sebelum penalitian maka dilakukan penelitian observasi terlebih dahulu terhadap kondisi awal karakter sopan santun pada anak kelompok B Tahun pelajaran 2019-2020 RA ADIRASA JUMIANG, observasi tersebut dilakukan dengan mewawancarai guru dan mengamati anak. Hasilnya, dari karakter masing-masing anak itu berbeda berdasarkan analisis data karakter diajarkan melalui pembiasaan sehari-hari. Observasi tersebut dolakukan dengan lembar Observasi anak yang sudah direncanakan oleh peneliti diperoleh hasil total skor karakter sopan santun anak pada siklus pecapaiannya tidak semuanya berhasil ada sebagian anak yang sulit diatur sopan santunnya terutama dalam bersikap atau berperilaku 3 orang anak masih sulit diarahkan dan 8 orang anak bisa diatur karakternya terutama dalam bersikap dan yang paling aktif 5 anak serta memiliki karakter sopan santun paling baik di kelas. Dalam proses bermain peran pun anak tersebut bisa diarahkan. Berdasarkan hasil tersebut dan tinjauan pustaka yg telah penulis lakukan serta konsultasi dengan narasumber atau (Dosen pembingbing) penulis akhirnya mengamvil keputusan untuk membauat tindakan dsalam rangka mengembangkan karakter sopan santun anak didik kelompok B Adirasa Jumiang salah satunya dengan menerapkan kegiatan metode bermain peran.

Kegiatan ini dilaksanak dalam dua pertemuan. Pertemuan pertama, dilaksanakan pada hari Jum'at, 25 oktober 2019, pertemuan kedua hari Senin, 28 oktober 2019. Penelitian ini menggunakan buku cerita yang bertemakan binatang (kelinci) adapun alat dan bahan yang dibutuhkan dalam persiapan cerita adalah kertas origami, pensil, gunting, gambar kelinci yg sudah di print, yang sudah disediakan oleh peneliti. Adapun cara membuat bahan dan alat dalam proses bercerita (mendongeng), a) guru menyiapkan kertas origami yang sudah dilipat membentuk kelinci sesuai dengan jumlah siswa, b) guru memyiapkan kertas origami berwarna hijau dan orange yang dilipat dan digunting membentuk rumput dan wortel sebagai makanan kelinci, c) guru menyiapkan wadah besar (keranjang besar) sebagai tempat proses bermain peran atau jalannya cerita.

Dari hasil pengamatan yang dilakikan peneliti pada siklus 1,anak bisa merngenal langsung nama-nama keluaraga kelinci yang diperankan seperti, ayah, ibu, adik, paman, orangbaru, sahabat. Pada siklus 2, anak bisa mengenal benda-benda yang ada di lingkungan sekitar. Anak bisa aktif dan bisa bberimajinasi terkait peran yang diperankan, dan dapat 
melatih daya ingat anak terkait nama tokoh yang diperaaaaanakan. Serta dapat meninglatkan motorik kasar anak seperti menirukan gerakan kelinci. Anak bisa mengambil pelajaran atau hikmah sesuai yang diceritakan seperti tolong menolong pada orang baru atau orang sekitar. Dan pada siklus 3, terkait perkembnagan dan kermempuan anak ususnya dalam bermain peran. Kemampuan bhasa dan kognitignya sudah berkembang, seperti nama binatang, sayuran, dan tanaman Serta anak sudah bisa mewarnai gambar sesuai dengan lingkungan sekitar.

Hasil observasi karakter sopan santun anak dengan metode bermsin peran menunjukkan peningkatan rata-rata persentase pencapaian karakter sopan santun, yaitu dari prasiklus $45 \%$ setelah dilakukan tindakan ke siklus 1 menjadi 70\%. Dalam pelaksanan tindakan siklus I ini, sudah tidak ada lagi anak yang prosentase pencapaian dengan kategori belum berkembang. Anak yang sudah tuntas atau mencaapi persentase pencapaian keberhasilan yang ditetapkan bertambah 3 menjadi 3 anak (15\%).

Dari lembar observasi kinerja guru siklus 1 dalam penerapan metode bermain peran dengan pengamat penulis mendapatkan fakta bahwa dari pengamatan terdapat 20 aspek, namun yang dikembangkan hanya 6 aspek saja. yang saudah dilaksanakan dengan baik. Diantaranya aspek agama moral, motorik, kognitif, bahasa, sosial emosional, dan seni, dengan skor $75 \%$ (sedang). , Adapun aspek yang berkembang diantaranya, 1) anak sudah mampu meniru apa yang sudah dicontohkan oleh guru dalam bermain peran seprti menerapkan keluarga kelinci, 2) anak sudah mampu mengenalkan kegiatan main yang sudah disiapkanb, 3) gurupun sudah mampu memberikan arahan atau gagasan tentang peran yang dimainkan, 4) serta guru mampu memberikan contoh terkait alat yang digunakan, serta guru siudah mampu menyampaikan karakter dari masing-masing tokoh dalam cerita, 5) namun, guru belum mampu mengatur permainan pada sebagian anak, 6) Guru sudah mampu mengajak anak untuk mengembalikan alat ketempat semula, namun hanya sebagian anak saja yang patuh kepada guru, serta sebagian anak sudah bisa menyesuaikan klasifikasi bentuk, ukuran dan penggunaan, benda, namun guru belum mampu memberi kesempatan kepada teman-temannya (anak didik) bertanya jawab, hanya memberi kesempatan tanya jawab antara guru kepada peserta didik saja.

Observasi dilakukan peneliti bersama dengan guru teman sejawat yang bertindak sebagai pengamat saat proses pembelajaran berlangsung. Dari hasil observasi selama siklus I diperoleh hasil bahwa (1) Anak-anak berebut setelah membaca dan mengamati bersama karena hanya disediakan 1 set untuk dibaca /diamati bersama, (2) Masih banyak anak yang memerlukan penjelasan yang lebih detail mengenai tema pertemuan, serta apa dan bagaimana hal-hal yang terkait dengan tema tersebut tersebut. Guru memerlukan penjelas berupa tambahan media atau alat peraga. Dalam hal ini anak memerlukan penjelasan berupa tambahan gambar tersebut, (3) Pada saat diajak berkeliling tempat main peran sebelum bermain peran oleh guru agar anak dapt mengenal tempat dan kegiatan main peran mereka. Anak-anak berebut tempat di tempat main,menyentuh alat main, dan lain-lainAnak seharusnya diajak berdiskusi dulu membahas aturan berkeliling ( memperhatikan bu guru, tidak menyentuh dulu, tidak berdesakdesakan dan lain-lain), (4) Anak-anak berebut 'peran' yang menarik bagi mereka, (5) Ketika memulai kegiatan main peran anak tampak bingung dengan peran mereka sehingga banyak yang salah masuk setting perannya, (6) Beberapa anak harus dipancing untuk mengemukakan pendapat atau bertanya karena malu. Ini dapat tampaak dari raut muka, gerakaan tubuh.Anak harus diberi kesempatan bertanya dalam memahami peran di tempat main dengan dorongan dukungan pancingan pertanyaan, 7) Pada pada proses bermain peran anak belajar tolong-menolong antar sesama sesuai yang diceritan dalam cerita, 8)saat menuliskan pengalaman main peran dan anak diminta mengingat apa yang telah diperankan, seperti nama-nama tokoh yang ada dalam cerit, 9).anak tampak kesulitan mengingat-ingat, 10) Pada saat menceritakan pengalaman bercerita mengenai 
pengalaman main mereka dan anak diminta mengingat cerita yang mereka perankan, siapa tokohnya, siapa saja anggota kelompoknya, gambar apa yang diamati tersebutsebagian anak tampak kesulitan mengingat-ingat, 11) Ketika guru memberi tanda waktu bermain kurang 5 menit habis, ada sebagian anak yang masih sibok dengan pemainannya sendiri. Namun, 75\% anak sudah bisa diajak bermain peran dan ikut memerankan tokoh yang sudah ditentukan.

Perencanaan tindakan siklus II dilakukan berdasar pada refleksi siklus I yang telah dibuat peneliti berdasar analisis observasi tindakan siklus I. Pada Tindakan II, proses pembelajaranberlangsung. Peneliti dibantu guru teman sejawat sebagai pengamat melakukanobservasi sesuai dengan pedoman yang telah dibuat peneliti. Siklus kedua dilaksanakan dalam dua pertemuan. Pertemuan Pertama dilaksanakan pada jum'at 25 oktober 2019, pertemuan kedua hari Senin 28 oktober 2019. Pada siklus II ini tema yang digunakan adalah binatang/kelinci. Pada pertemuaan pertama pembelajaran menggunakan sub tema binatang/kelinci.

Observasi siklus II dilakukan pada saat proses pembelajaranberlangsung. Peneliti dibantu guru dan kepala sekolah melakukanobservasi sesuai dengan pedoman yang telah dibuat peneliti.Berdasarkan observasi yang telah dilakukan peneliti dibantu guru dan kepala sekolah, diperoleh hasil observasi bahwa: (1) Pembagian peran yang dilakukan dengan membuat peran yang tampak menarik bagi anak untuk 2 anak atau lebih membuat anak yang semula berebut segera tampak menerima pembagian dengan puas, (2) Masih terdapat anak yang kurang puas mendapati dirinya tidak biasa menguasai penuh buku cerita pendek. Anak ini meminta gambar yang bisa mereka lihat, (3) Masih ada beberapa anak yang masih harus dimotivasi untuk melakukan perannya. Ada sebagian dari mereka yang hanya diam saja tidak melakukan apapun kecuali disuruh guru atau teman, (4) Ketika mulai bermain peran anak-anak sudah langsung bisa menempati setting peran mereka masing-masing setelah mereka mencocokkan kartu dada mereka yang menunjukkan nama dan peran mereka dengan setting yang telah diberi nama peran masing-masing, (5) Dalam melakukan peran kelinci penolong anak-anak tampak menikmati dalam menggunakan media kelinci (gambar kelinci), (6) Anak sudah mulai bisa bermain peran dengna perencanaan bersama baik dengan guru dan siswa. Hal tersebut tampak ketika kebanyakan anak bisa 'sharing pengalaman' dengan teman. Tetapi yang menjadi kendala adalah saat anak ketika melakukan permainaan peran anak sulit memperagakan secara lngsung, jadi guru masih memberikan contoh gerakan sesuai cerita hanya sebagian gerakan saja tang bisa ditiru oleh anak tidak secara keseluruhan. Ketika waktu habis anak masih sulit mengingat apa yang mereka perankan. Jadi, guru masih perlu melakukan pengulangan kembali dengan metode check list dan quistion. Pada hasil refleksi siklus II fakta yang nampak adalah pelaksanaan tindakan pada Siklus II, sudah berjalan denganbaik.Pada siklus ini secara garis besar sudah terdapat peningkatan kemampuan yang sangat signifikan.

Pada saat mengakhiri pelajaran jika anak bisa menjawab ia diberi kesempatan pulang terlebih dahulu, namun hanya sebagian saja yang berhasil. Dalam pelaksanan tindakan siklus II ini, .terjadi peningkatan persentase pencapaian karakter sopan santun sebesar 22,62\% dari 61,25 di prasiklus menjadi 73,87 di siklus I. Anak yang sudah tuntas atau mencapai persentase pencapaian keberhasilan yang ditetapkan bertambah menjadi 7 anak (75\%). Hanya terdapat $3(15 \%)$ anak yang prosentase pencapaiannya berkategori mulai berkembang. Pelaksanaan tindakan proses pembelajaran dengan metode bermain peran sudah sesuai dengan perencanaan pada rencana bidang pengembangan yang telah disusun. Waktu yang dialokasikan 60 menit untuk kegiatan inti pembelajaran bisa dimanfaatkan dengan baik dalam pembelajaran karena guru bisa memberi pijakan berupa motivasi, teguran atau modeling kepada anak. Guru juga bisa mengingatkan siswa akan batasan waktu kegiatan mereka. Anak tidak menemui banyak kesulitan melakukan langkah pembelajaran 
karena anak membentuk komunitas-komunitas sendiri yang bisa saling mencocoki dalam membuat interaksi berupa komunikasi di antara mereka untuk membuat skenario cerita maupun untuk sharing pengalaman. Salah satu kegiatan guru memberi motivasi adalah ketika berada pada kegiatan presentasi bercerita pengalaman main. Sudah tidak ada anak yang mendominasi kegiatan belajar karena keaktivannya maupun kemampuan bahasa yang tinggi. Selain itu guru juga memberi penguatan kepada mereka untuk selalu mentaati aturan yang telah mereka buat dan sepakati bersama.

Pada siklus III anak sudah banyak mdengalami peningkatan salah satunya bisa mwewarnai sesuai dengan kreasinya sendirai dan sudah bisa tidak melebihi garis ketika mewarnai. guru lebih banyak memberikan kesempatan kepada siswa untuk aktif, dan berpartisipasi dalam pembelajaran, terutama anak-anak yang belum aktif atau belum percaya diri dengan menunjuk dan memberikan kesempatan kepada siswa untuk bertanya, menjawab pertanyaan, mengemukakan pendapat dan memberikan tanggapan juga dengan memotivasi siswa untuk terlibat dalam pembelajaran. Hal tersebut cukup efektif terbukti aktivitas pembelajaran tidak didominasi oleh siswa yang terbiasa aktif. Misalnya, ketika usai bermain peran guru memberikan pertanyaan pada peserta didik terkait dengan yang diceritakan, untuk membuktikan berkembang tidaknya 6 aspek perkembangan pada anak usia dini. Dengan adanya metode tanya jawab tersebut akan melatih anak dalam keberaniannya baik itu dalam mengungkapkan pendapat atau dari pengetahiuan yang dimilikinya. Ketika anak sudah bisa menjawab pertanyaan dari guru berti ia sudah mengalami peningkatan baik dari segi kognitif berfikir atau mengingat dan bahasanya. Setiap anak memiliki kemampuan perkemangan yang berbeda-beda bisa dinilai dari segi sifat dan karakter, perilaku dalam kehidupan sehari-hari. Sedang anak yang tidak aktif ia pun sudah mulai berani meskipun tidak tampak secara utuh. Dengan adanya quistion didampingi dengan permainan peran anak akan mulai berani mengungkapkan yang ia ketahui tentang cerita yang disampaikan oleh guru. Anak pun akan mulai menghilangkan sedikit rasa malu yang ada dalam dirinya, karena ia sudah mulai berkolaborasi dengan lingkungan sekiarnya terutama pada teman dan guru, tyerutama pada orang baru. Aktivitas anak yang kurang menunjang dalam pembelajaran, seperti bermain sendiri, tidur, atau bergurau dengan temannya sudah mulai berkurang.

Pada saat proses pengamatan siswa sudah mampu bekejasama dalam kelompok secara baik sehingga mereka dalam melakukan pengamatan ketika guru memberikan apersepsi saat kegiatan awal maupun ketika guru bercerita pada kegiatan awal, dan ketika setiap kelompok harus melakukan presentasi cerita dengan pengalaman main, mereka tidak lagi menunggu bimbingan guru, namun demikian masih ada pula kelompok yang membutuhkan bimbingan guru karena saat penjelasan langkah-langkah pengamatan mereka kurang memperhatikan. Sudah muncul bentuk kreativitas anak dalam menyelesaikan permasalahan yang mereka hadapi.

\section{KESIMPULAN}

Berdasarkan hasil penelitian tindakan kelas yang dilakukan, diketahuibahwa terjadi peningkatan karakter sopan santun anak dari Siklus I sampai dengan Siklus III. Rata-rata persentase pencapaian kemampuan membaca awal anak meningkat berturut-turut dari prasiklus, sikus I dan siklus III. Rata-rata persentase pencapaian kemampuan karakter sopan santun anak meningkat berturut-turut dari prasiklus, sikus I dan siklus III. Berturut-turut $45 \%$ pada kondisi prasiklus meningkat menjadi $70 \%$ pada siklus I, $22,62 \%$ di siklus II. Sedangkan jumlah anak yang tuntas belajar atau mencapai prosentase keberhasilan sebesar $75 \%$ juga terus anak yang prasentase pencapaiannya yang berkatagori mulai berkembang. Dan pada siklus III, anak sudah banyak mdengalami peningkatan salah satunya bisa mwewarnai sesuai dengan kreasinya sendirai dan sudah bisa tidak melebihi garis ketika mewarnai.. Dengan demikian hipotesis yang berbunyi bahwa didug amelalui kegiatan 
P-ISSN:

E-ISSN:

bermain peran dapat mengembangkan karakter sopan santunpada anak pada RA Adirasa Jumiang Muballighin II Tahun Pelajaran 2019-2020 teruji kebenarannya.

\section{DAFTAR PUSTAKA}

Kusuma, dewi. 2012. Pemasaan sopan santun untuk Anak. Tersedia dalam http://indteacher.wordpress.com/2009/05/06/. Di unduh pada tanggal 8 april 2013

Megawangi, Ratna. 2007. Seтua Berakar pada Karakter. Tersedia dalam http://www.langitperempuan.com/2008/02/ratna-megawangipeloporpendidikanholistik-berbasis-karakter/

Supriyanti. (2008). Sopan Santun dalam pendidikan karakter. Jakarta: GP Pres.

Yusuf, 2006, psikologi perkembangan anak dan remaja, bandung: rosda

$\underline{\text { www.kamusBahasaindonesia.org }}$ 